Volume 11, Nomor 1, Mei 2019, pp 12 - 21 Copyright (C) 2017 Jurnal Akuntansi Maranatha, Program Studi Akuntansi, Fakultas Ekonomi,Universitas Kristen Maranatha. ISSN 2085-8698 | e-ISSN 2598-4977. http://journal.maranatha.edu

\title{
Pengaruh Penerapan Enterprise Risk Management (COSO) Terhadap Nilai Perusahaan:Studi Empiris pada Perusahaan Manufaktur yang Terdaftar di BEI
}

\author{
Adie Pamungkas \\ Pascasarjana Universitas Katolik Parahyangan \\ Magister Manajemen \\ (Jln.Merdeka No.30, Babakan Ciamis, Sumur Bandung, Kota Bandung Jawa Barat) \\ adisaid14@gmail.com
}

\begin{abstract}
In the business world there are lot of uncertainties, every activity carried out or decisions taken always had risks, both small and large. The intelligence of managers, the technological sophistication used even the age of the company will not guarantee success. Today many old companies suddenly go bankrupt, including in Indonesia, the inability of companies to manage risk is the most fatal mistake. This study aims to determine the effect of the application of Enterprise risk management (COSO) on Corporate Value with the Price Book Value (PBV) method.

The research method used is descriptive analysis method that is a method that describes what happens to the company based on the facts or events at the company. The author uses a purposive sampling method. The data used is secondary data sourced from annual reports from the 10 best manufacturing companies of the Forbes magazine listed on the Indonesia Stock Exchange for the period 2012-2015.

The results of testing the data show that Enterprise risk management has an influence on Company Value. Based on the results of calculations So $4.186 t$ count $>2.02 t$ table. While the significant level is 0,000<0,05. This indicates that ERM has a positive effect on Company Value.
\end{abstract}

Keyword: Enterprise Risk Management: COSO: Corporate Value: Price Book Value $(P B V)$

\section{Pendahuluan}

Pesatnya perubahan teknologi, globalisasi, dan perkembangan transaksi menyebabkan makin tingginya tantangan yang dihadapi perusahaan dalam mengelola risiko yang harus dihadapinya (Beasley et al,
2008).Manajemen risiko atau EnterpriseRisk Manajemen (ERM) merupakan suatustrategi yang digunakan untuk mengevaluasi dan mengelola semua risiko dalamperusahaan.Pendekatan terhadap pengelolaan risiko organisasi sering disebut dengan manajemen risiko.

Di tengah situasi perekonomian yang penuh ketidakpastian persaingan 
bisnis serta kompleksnya risiko bisnis yang harus dihadapi perusahaan, sistem manajemen risiko merupakan salah satu perangkat utama untuk mengurangi dan menangani setiap risiko yang mungkin timbul (Beasley et al., 2006;).

Pada tahun 2001 terungkap skandal akuntansi yang melibatkan perusahaan besar, Enron.Perusahaan ini pernah mendapat peringkat 7 dari daftar Fortune500.Perusahaan energi terbesar di Amerika Serikat ini bangkrut dengan meninggalkan hutang hingga US\$ 31 milyar (www.bbc.co.uk).Kasus ini membuktikan bahwa memanage risiko itu sangat penting.

Praktik manajemen risiko dan pengungkapan risiko menarik perhatian dunia setelah skandal akuntansi besar dan kejatuhan perusahaan di awal tahun 2000an (Power, 2004, dalam Zhang, et al., 2013) serta krisis keuangan global pada tahun 2008 (Kirkpatrick, 2009).Kejadian ini melibatkan perusahaan yang telah berumur ratusan tahun seperti Enron dan Lehman Brothers.Bagaimanapun, kebangkrutan beberapa perusahaan seperti Enron, Tyco, WorldCom mengindikasikan prinsip ERM tidak efektif diterapkan baik pada pasar negara maju maupun negara berkembang termasuk Indonesia (Husaini,etal., 2013: 1).

Penelitian oleh $\begin{array}{r}\text { Mercer } \\ \text { Management terhadap }\end{array}$ kegagalan
perusahaan yang termasukdalamFortune 1000 selama tahun 1993-1998 menunjukkan bahwa 58\% kerugian dipicu oleh risiko strategis yang gagal dikelola serta penelitian oleh $\mathrm{Booz}$ Allen Hamilton terhadap 1.200 perusahaan dengan nilai kapitalisasi pasar lebih dari US\$1 triliun selama tahun 1999-2003 menunjukkan bahwa dari 360 perusahaan berkinerja terburuk, $87 \%$ penyebab kerugian berasal dari risiko strategis yang gagal dikelola (Christina, 2013). Hasil penelitian- penelitian ini sekaligus menunjukkan bahwa manajemen risiko perusahaan belum efektif diterapkan dan penerapan manajemen risiko mempengaruhi kinerja perusahaan.

Praktik manajemen risiko di Indonesia masih terbilang baru. Hanya sektor perbankan saja yang memiliki aturan sendiri tentang manajemen risiko karena sektor ini memiliki lebih banyak risiko dibanding sektor lain. Sedangkan untuk sektor lainnya praktik manajemen risiko sendiri masih digabungkan dengan praktik GoodCorporate Governance (GCG) sehinggabelum efektif.Kemudian baru pada tahun 2012, Komite Nasional Kebijakan Governance (KNKG) mengeluarkan Pedoman Manajemen Risiko Berbasis Governance yang terpisah dari Pedoman GCG.Tetapi aturan ini hanya sebatas dorongan etika atau hanya sebatas anjuran saja dan tidak memiliki ikatan hukum yang mewajibkan perusahaan untuk mengikuti aturan tersebut.

$$
\text { Asia Risk Report }
$$

(2013:5)mengungkapkan bahwa Indonesia memiliki lima risiko yang paling perlu diperhatikan yaitu ketidakpastian politik, perubahan peraturan, ketahanan dan perpindahan SDM, kondisi ekonomi, dan hubungan industrial. Risiko ketidakpastian politik berkaitan dengan pemilihan kepala pemerintahan.Perubahan peraturan terutama peraturan yang berkaitan dengan lingkungan hidup semakin ketat seiring dengan kesadaran masyarakat. Ketahanan dan perpindahan SDM berkaitan dengan bagaimana perusahaan merekrut pegawaibaru, memberdayakannnya,serta mempertahankan pegawai yang berprestasi. Kondisi ekonomi misalnya defisit neraca perdagangan, yang secara makro dapat mempengaruhi keadaan industri khususnya ekspor - impor. Johan Candra, pakar ERM PT XL Axiata, dalam Asia Risk Report Indonesia (2013: 8), mengatakan bahwa dalam skala $1-5$, Indonesia punya nilai 2 (dua) dalam ERM rate of maturity di mana 5 (lima) merupakan nilai tertinggi. Kenyataanya memang menunjukkan penerapan manajemen risiko perusahaan di Indonesia masih rendah. 
Objek penelitian ini adalah perusahaan manufaktur yang terdaftar di BEI tahun 2012 -2015.Alasan pemilihan objek penelitian ini adalah karena sektor industri manufaktur merupakan kontributor terbesar bagi pendapatan domestik bruto (PDB) Indonesia selama dua dekade terakhir.

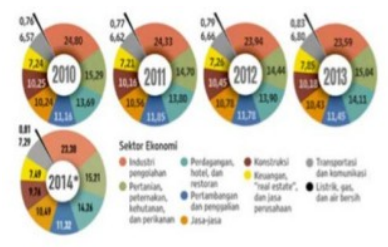

\section{Gambar 1 \\ Kontribusi terhadap PDBmenurut Lapangan Usaha (persentase)}

Berdasarkan data tersebut penulis tertarik untuk melakukan penelitian yang berjudul "Pengaruh Penerapan Enterpriserisk management (COSO) terhadap nilaiperusahaan" (studi kasus pada perusahaan manufaktur yang terdaftar di BEI periode 2012-2015).

Berdasarkan uraian diatas, penelitian ini bertujuan untuk memberikan bukti empiris mengenai pengaruh positif penerapan manajemen risiko (COSO) terhadap nilai perusahaan. Pada bagian selanjutnya akan dibahas mengenai kerangka teoritis yang berisi definisi konsep dasar dan pengembangan hipotesis. Metode penelitian akan diuraikan pada bagian selanjutnya diikuti dengan hasil penelitian dan pembahasan. Bagian terakhir diuraikan simpulan dan saran bagi penelitian di masa mendatang.

\section{Kerangka Teoritis dan Hipotesis}

\section{Manajemen Risiko (COSO)}

Dalam Excecutive Summary yang dikeluarkan oleh COSO (2004), yang dimaksud dengan Enterprise riskmanagement (ERM) adalah sebuah prosesyangdipengaruhi oleh dewan direksi, manajemen, dan personil lainnya yang diterapkan dalam pengaturan strategi dan mencakup perusahaan secara keseluruhan, dirancang untuk mengidentifikasi peristiwa potensial yang dapat memengaruhi perusahaan dan mengelola risiko yang berada dalam batasannya untuk memberikan keyakinan yang cukup yang berkaitan dengan pencapaian tujuan perusahaan.

COSO menyatakan bahwa Enterprise riskmanagement meliputi enam hal berikut:

1. Aligning risk appetite and strategy

Manajemen mempertimbangkan besarrisiko entitas dalam mengevaluasi strategi alternatif, menetapkan tujuan yang terkait, dan mengembangkan mekanisme untuk mengelola risiko yang terkait.

2. Enchancing risk response decisions

ERM menyediakan kekuatan untuk mengidentifikasi dan memilih diantara tanggapan alternatif risiko - mennghindari, mengurangi, membagi, dan menerima risiko.

3. Reducing operational surprises and losses

Keuntungan entitas meningkatkan kapabilitas untuk mengidentifikasi peristiwa potensial dan menetapkan respon, mengurangi kejutan, dan menghubungkan dengan biaya atau kerugian.

4. Identifiying and managing multiple and cross-enterprise risks

Setiap perusahaan menghadapi banyak sekali risiko yang memengaruhi berbagai bagian 
organisasi dan Enterprise riskmanagement memfasilitasi respon yangefektif terhadap dampak yang saling berhubungan dan mengintegrasikan respon terhadap beberapa risiko.

5. Seizing opportunities

Dengan mempertimbangkan berbagaiperistiwa potensial, manajemen diposisikan untuk mengidentifikasi dan secara proaktif merealisasikan peluang.

6. Improving deployment of capital Memperoleh informasi risiko yangkuat memungkinkan manajemen untuk secara efektif menilai kebutuhan modal secara keseluruhan dan meningkatkan alokasi modal.

Dari keenam hal tersebut, dapat dilihat bahwa Enterprise risk management (ERM) mengatasi risiko melalui identifikasi, evaluasi, meminimalkan biaya yang ditimbulkan oleh risiko, serta melihat kemungkinan kejadian potensial yang dapat menyebabkan kerugian.

COSO (2004), menjelaskan bahwa efektivitas ERM suatu organisasi harus dinilai dari empat tujuan ERM berikut: (1) Strategi, merupakan tujuan tingkat tinggi, sejalan dan mendukung misi organisasi; (2) Operasi, yaitu berkaitan dengan penggunaan sumber daya yang efektif dan efisien; (3) Pelaporan, yang menitik beratkan pada keandalan pelaporan keuangan; dan (4) Kepatuhan, meliputi mematuhi hukum dam peraturan yang berlaku.

\section{Nilai Perusahaan}

Nilai Perusahaan didefinisikan sebagai nilai pasar karena Nilai Perusahaan dapat memberikan kemakmuran pemegang saham secara maksimum apabila harga saham perusahaan meningkat.Berbagai kebijakan yang diambil oleh manajemen dalam upaya untuk meningkatkan NilaiPerusahaan melalui peningkatan kemakmuran pemilik dan para pemegang saham yang tercermin pada harga saham. (Bringham \& Houston, $2006: 19)$.

Konsep nilai suatu perusahaan Menurut Chistiawan dan Tarigan (2007), terdapat beberapa konsep nilai yang menjelaskan nilai suatu perusahaan antara lain :

1. Nilai Nominal, yaitu nilai yang tercantum secara formal dalam anggaran dasar perseroan, disebutkan secara eksplisit dalam neraca perusahaan, dan juga ditulis jelas dalam surat saham kolektif.

2. Nilai pasar sering disebut kurs adalah harga yang terjadi dari proses tawar menawar di pasar saham. Nilai ini hanya bisa ditentukan jika saham perusahaan dijual di pasar saham.

3. Nilai intrinsic merupakan nilai yang mengacu pada perkiraan nilai riil suatu perusahaan. Nilai Perusahaan dalam konsep nilai intrinsic ini bukan sekedar harga dari sekumpulan aset, melainkan Nilai Perusahaan sebagai entitas bisnis yang memiliki kemampuan menghasilkan keuntungan di kemudian hari.

4. Nilai buku adalah Nilai Perusahaan yang dihitung dengan dasar konsep akuntansi.

5. Nilai likuidasi adalah nalai jua seluruh asset perusahaan setelah dikurangi semua kewajiban yang harus dipenuhi. Nilai sisa itu merupakan bagian para pemegang saham. Nilai likuidasi bisa dihitung berdasarkan neracaperforma yang disiapkan ketika suatu perusahaanakan dilikuidasi.

Berdasarkan teori dan uraian diatas, maka dapat disimpulkan hipotesis sebagai berikut: 


\section{H1:PenerapanEnterprise riskmanagement berpengaruh terhadap nilaiperusahaan.}

\section{Metode Penelitian}

\section{Data Penelitian}

Data yang digunakan dalam penelitian ini adalah data sekunder.Data didapat dari laporan tahunan perusahaan-perusahaan manufaktur yang sudah go-public atau sudah terdaftar di Bursa Efek Indonesia.Sampel ditentukan dengan menggunakan metode purposive sampling. Adapun kriteria-kriteria khusus untuk menentukan sample nya, kriterianya yaitu :

1. Perusahaan manufaktur yang masuk dalam daftar 50 perusahaan terbaik versi majalah Forbes tahun 2016

2. Perusahaan yang masuk dalam daftar tersebut harus terdaftar juga di BEI

3. Perusahaan manufaktur yang go public(melaporkan laporantahunan dari tahun 2012-2015).

Perusahaan-perusahaan yang dijadikan sampel dalam penelitian ini yaitu:

\begin{tabular}{|c|l|}
\hline $\begin{array}{c}\text { Kode } \\
\text { Perusahaan }\end{array}$ & \multicolumn{1}{c|}{ Nama Entimen } \\
\hline ASII & Astra Intemasional \\
\hline EKAD & Ekadhama Intemasional \\
\hline NDF & Indofood Sukses Makmur \\
\hline KBLI & Kmi Wire And Cable \\
\hline SMGR & Semen Indonesia \\
\hline SRIL & Pt.Sn Rejeki Isman \\
\hline TMPO & Tempo IntiMedia \\
\hline AISA & Tiga Pilar Sejahtera Food \\
\hline UNVR & Unilever Indonesia \\
\hline & $\begin{array}{l}\text { PT.Wilmar Cahaya } \\
\text { Indonesia }\end{array}$ \\
\hline CEKA &
\end{tabular}

Definisi Operasional Variabel dan Pengukurannya

\section{Manajemen Risiko (COSO)}

Pemahaman manejemen risiko

memungkinkan manajemen untuk terlibat secara efektif dalam menghadapi ketidak tentuan dengan risiko dengan risiko dan peluang yang berhubungan danmeningkatkan kemampuan organisasi untuk memberikan nilai tambah. Menurut COSO ERM (2004), proses manajemen risiko dapat dibagikan ke dalam 8 kompenen. Sebagaimana dijelaskan pada gambar berikut ini :

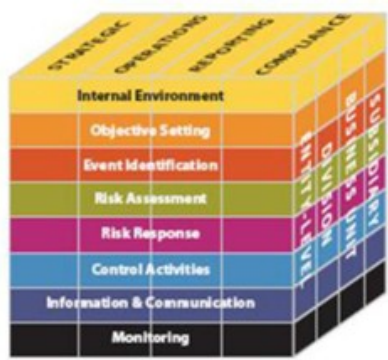

\section{Gambar 2}

Komponen ERM

a. Internal environment

Lingkunganinternalsangatmenentu kan warna dari sebuah organisasi dan memberi dasar bagi cara pandang terhadap risiko dari setiap orang dalam organisasi tersebut. Di dalam lingkungan internal ini termasuk, filosofi manajemen risiko dan risk appetite, nilai-nilai etika dan integritas, dan lingkungan di mana kesemuanya tersebut berjalan.

b. Objective setting

Tujuan perusahaan harus ada terlebih dahulu sebelum manajemen dapat menidentifikasi kejadian-kejadian yang berpotensi mempengaruhi pencapaian tujuan tersebut. ERM memastikan bahwa manajemen memiliki sebuah proses untuk menetapkan tujuan ddan bahwa tujuan yang dipilih atau ditetapkan tersebut terkait dan mendukung misi perusahaan dan konsisten dengan risk appetitenya. 
c. Event identification

Komponen ini mengidentikasi kejadian-kejadian potensial baik yang terjadi di lingkungan internal maupun eksternal organisasi yang mempengaruhistrategi atau pencapaian tujuan dari organisasi.Kejadian tersebut bisa berdampak positif (opportunities), namun dapat pua sebaliknya atau negatif (risks).

d. Risk assasment

Komponen ini menilai sejauhmana dampak dari event (kejadian atau keadaan) dapat mengganggu pencapaian dari objectives. Besarnya dampak dapat diketahui dari inherent dan residual risk, dan dapat dianalisi dalam dua perspektif, yaitu :likelihood (kecenderungan atau peluang) dan impact/consequence (besaran dari tereasliasinya resiko). Dengan demikian, besarnya risiko atas setiap kegiatan organisasi merupakan perkalian antara likelihood dan consequence.

e. Risk response

Organisasi harus menentukan sikap atas hasil penilaian risiko.Risk response dari organisasi dapat berupa: (1) avoidance, yaitu dihentikannya aktivitas atau pelayanan yang menyebabkan risiko; (2) reduction, yaitu mengambil langkah-langkah mengurangi likelihood atau impact dari risiko; (3) sharing, yaitu mengalihkan atau menanggung bersama risiko atau sebagian dari risiko dengan pihak lain; (4) acceptance, yaitu menerima risiko yangterjadi (biasanya risiko yang kecil), dan tidak ada upaya khusus yang dilakukan.

\section{f. Control activities}

Komponen ini berperanan dalam penyusunan kebijakan-kebijakan (policies) dan prosedur -prosedur untuk menjamin risk response terlaksana dengan efektif.Aktifitas pengendalian memerlukan lingkungan pengendalian yang meliputi:

(1)integritas dan nilai etika; (2) kompetensi; (3) kebijakan dan praktik-praktik SDM; (4) budaya organisasi; (5) filosofi dan gaya kepemimpinan manajemen; (6) struktur organisasi; dan (7) wewenang dan tanggung jawab.

g. Information and communication Fokus dari komponen ini adalah menyampaikan informasi yang relevan kepada pihak terkait melalui media komunikasi yang sesuai. Faktor-faktor yang perlu diperhatikan dalam penyampaian informasi dan komunikasi adalah kualitas informasi, arah komunikasi, dan alat komunikasi.

h. Monitoring

Monitoring dapat dilaksanakan baiksecara terus menerus (ongoing) maupun terpisah (separate evaluation).Aktifitas monitoring ongoing tercermin pada aktivitas supervisi, rekonsiliasi, dan aktivitas rutin lainnya.Dimana setiap komponen memiliki pernyaan tersendiri untuk mengungkapkan ERM. Dengan total pernyaan sejumlah 108 pernyataan.

\section{Nilai Perusahaan}

Metode atau ukuran yang digunakan untuk meneliti nilai perusahaan adalah metode Price to Book Value (PBV) dimana Price to Book Value (PBV) menggambarkanseberapa besar pasar menghargai nilai bukusaham suatu perusahaan.

$$
P B V=\frac{\text { harga perlembar saham }}{\text { nilai buku perlembar saham }}
$$




\section{Metode Analisis Data}

\section{Uji Kualitas Data}

\section{Uji Hipotesis}

Pengujian hipotesis menggunakan analisis regresi linier sederhana.Serangkaian pengujian yang dilakukan adalah uji koefisien determinasi, dan uji $\mathrm{T}$.

\section{Hasil Penelitian dan Pembahasan}

\section{Manajemen Risiko (COSO)}

Tabel 1

\section{Hasil Indeks ERM (COSO)}

\begin{tabular}{|c|c|c|c|c|c|c|}
\hline \multirow{2}{*}{ No } & \multirow{3}{*}{ Kode } & \multicolumn{5}{|c|}{ Enterprise Risk Management } \\
\cline { 3 - 7 } & 201 & $\begin{array}{c}201 \\
3\end{array}$ & $\begin{array}{c}201 \\
4\end{array}$ & $\begin{array}{c}201 \\
5\end{array}$ & $\begin{array}{c}\text { Rata- } \\
\text { Is: }\end{array}$ \\
\hline 1 & ASII & 0,80 & 0,80 & 0,80 & 0,80 & 0,80 \\
\hline 2 & EKA & 0,72 & 0,72 & 0,76 & 0,8 & 0,75 \\
\hline 3 & INDF & 0,80 & 0,80 & 0,80 & 0,84 & 0,81 \\
\hline 4 & KBLI & 0,72 & 0,72 & 0,72 & 0,72 & 0,72 \\
\hline 5 & SMGR & 0,96 & 0,96 & 0,76 & 0,96 & 0,96 \\
\hline 6 & SRIL & 0,76 & 0,8 & 0,68 & 0,72 & 0,74 \\
\hline 7 & TMPO & 0,68 & 0,72 & 0,72 & 0,72 & 0,71 \\
\hline 8 & AISA & 0,72 & 0,92 & 0,72 & 0,84 & 0,80 \\
\hline 9 & UNVR & 0,80 & 0,80 & 0,80 & 0,76 & 0,79 \\
\hline 10 & CEKA & 0,76 & 0,76 & 0,76 & 0,76 & 0,76 \\
\hline Rata-rata & 0,77 & 0,80 & 0,75 & 0,80 & 0,78 \\
\hline
\end{tabular}

Berdasarkan hasil tersebut dapat diketahui bahwa penerapan manajemen risiko yang paling baik antara 2012 sampai 2015 ada di perusahaan PT.Semen Indonesia.

\section{Nilai Perusahaan}

Tabel 2

Hasil Nilai Perusahaan

\begin{tabular}{|c|c|c|c|c|c|c|}
\hline \multirow[b]{2}{*}{$\begin{array}{l}N \\
0\end{array}$} & \multirow[b]{2}{*}{ Kode } & \multicolumn{5}{|c|}{ Price Book Value (Nilai Perusahaan) } \\
\hline & & 2012 & $\begin{array}{c}201 \\
3 \\
\end{array}$ & $\begin{array}{c}201 \\
4 \\
\end{array}$ & \begin{tabular}{|c|}
201 \\
5
\end{tabular} & $\begin{array}{l}\text { Rata- } \\
\text { rata }\end{array}$ \\
\hline 1 & ASII & 3,43 & 2,59 & 2,60 & 1,92 & 2,64 \\
\hline 2 & EXAD & 1,57 & 1,15 & 1,54 & 1,16 & 1,36 \\
\hline 3 & INDF & 1,50 & 1,51 & 1,45 & 1,05 & 1,28 \\
\hline 4 & KBLI & 0,89 & 0,64 & 0,61 & 0,46 & 0,65 \\
\hline 5 & SMGR & 5,18 & 3,85 & 4,09 & 2,46 & 3,90 \\
\hline 6 & SRIL & 1,19 & 1.96 & 1,19 & 1,89 & 1,56 \\
\hline 7 & TMPO & 0,87 & 0.93 & 0,93 & 0,53 & 0,82 \\
\hline 8 & AISA & 1,55 & 1,78 & 0,98 & 2,79 & 1,78 \\
\hline 9 & UNVR & 40,1 & 46,6 & 45,0 & 58,5 & 47,6 \\
\hline 10 & CEKA & 0,83 & 0,65 & 0,87 & 0,63 & 0,75 \\
\hline \multicolumn{2}{|c|}{ Rata-rata } & 5,71 & 6,17 & 5,93 & 7,14 & 6,23 \\
\hline
\end{tabular}

Berdasarkan hasil tersebut diketahuibahwadi Indonesia, perusahaan manufaktur yang paling tinggi nilai perusahaannya adalah PT.Unilever Indonesia diikuti oleh PT.Semen Indonesia di posisi kedua.

Uji Hipotesis

1. Analisis Regresi Linier Sederhana Teknik analisis data yang digunakanuntuk memecahkan permasalahan yang terdapat dalam penelitian ini adalah teknik analisis kuantitatif, yaitu analisis datadengan mengadakan perhitungan-perhitungan yang relevan dengan masalah yang dianalisis.

$\mathrm{Y}=\alpha+\beta 1 \mathrm{X} 1+\mathrm{e}$

Keterangan:

$\mathrm{Y}=$ Nilai Perusahaan (PBV)

$\alpha=$ Bilangan Konstanta

$\beta 1=$ Koefisien Regresi dari variabel independen

$\mathrm{X} 1=$ Enterprise risk management

$\mathrm{e}=$ Variabel Residual 
Tabel 3

Uji Regresi Sederhana

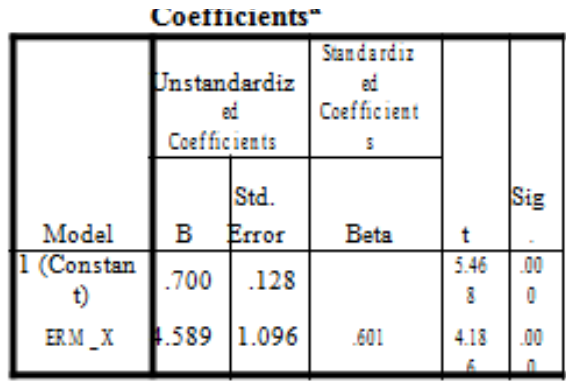

a. Dependent Variable: PBV_Y

Berdasarkan hasil perhitungan tabel diatas, maka dapat diperoleh bentuk persamaan regresi linier berganda sebagai berikut:

$$
Y=0.700+-4.589 X 1+e
$$

Persamaan regresi diatas dapat diinterprestasikan sebagai berikut:

a. Nilai konstanta dari persamaan diatas bernilai yaitu 0,700 . Hal ini merupakan nilai taksiran variable dependen jika Enterprise riskmanagement naik maka NilaiPerusahaan akan turun sebesar 4,589.

b. Nilai koefisien regresi variabel Enterprise risk management sebagai variabel Independen yaitu sebesar 4,689.

2. Koefisien Determinasi

Selain untuk menguji hipotesis, analisis regresi berganda juga digunakan untuk mengukur pengaruh variabel independen secara simultan terhadap variabel dependen serta untuk mengukur koefisien determinasi model penelitian. Untuk mengukur seberapa jauh kemampuan model dalammenerangkanvariasivariabeldepen den, maka digunakanlah koefisien determinasi. Dalam penelitian ini, nilai koefisien determinasi yang dipakai adalah nilai adjusted $\mathrm{R}$ Square. Tabel berikut ini menyajikan nilai koefisien determinasi dari model penelitian.

Dapat dilihat pada tabel dibawah ini, hasil analisis koefisien determinasi dengan menggunakan software aplikasi pengolah data dan statistika sebagai berikut:

Tabel 4

Uji Koefisien Determinan

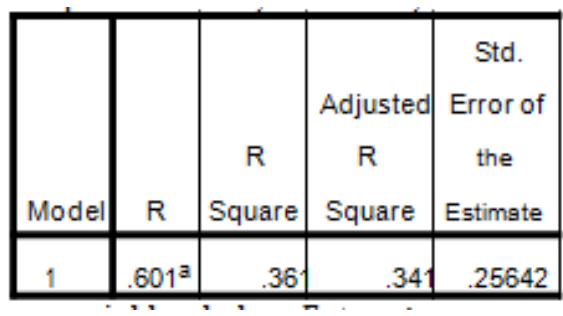

Berdasarkan tabel diatas diperoleh nilai R Square sebesar 0,361 atau 36,1\%. Hal inimenunjukkan bahwa Enterprise riskmanagement berpengaruh sebesar 36,1\%terhadap Nilai Perusahaan. Sedangkan sisanya sebesar 63,9\% dijelaskan oleh variabel lain diluar model.

3. Uji T

Uji-T pada dasarnya menunjukan seberapajauh pengaruh satu variabel penjelas/independen secara individual dalam menerangkan variasi variabel dependen.

Kriteria pengambilan keputusan

(LPEP, 2009) :

a. $\mathrm{t}$ hitung $\leq \mathrm{t}$ tabel maka Ho diterima dan Ha ditolak, itu berarti tidak ada pengaruh yang bermakna oleh variabel $\mathrm{X}$ dan $\mathrm{Y}$.

b. $t$ hitung $\geq t$ tabel maka Ho ditolak dan Ha diterima,itu berarti ada pengaruh yang bermakna oleh variabel X dan Y. 


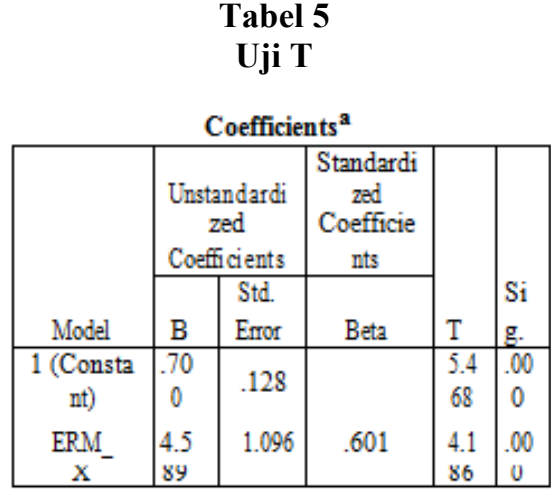

Berdasarkan tabel diketahui nilai thitung pada variabel Enterprise riskmanagement adalah sebesar 4,186 dengant tabel sebesar 2,02. Maka nilai t hitung lebih besar dari $t$ tabel. Sedangkan tingkat signifikan sebesar 0.00 , yang artinya lebih kecil dari 0,05 . Maka dapat dinyatakan bahwa Ho ditolak dan Ha diterima. Terlihat pada kolom koefisien bahwa enterprise riskmanagement memiliki nilai signifikan 0,00.Nilai signifikan lebih keil dari probabilitas 0,05 , atau nilai $0,00<0,05$, maka $\mathrm{H} 1$ diterima dan $\mathrm{H} 0$ ditolak. Variabel $\mathrm{X}$ mempunyai nilai $\mathrm{t}$ hitung 4,186 dengan $t$ tabel sebesar 2,02.. Jadi $\mathrm{t}$ hitung 4,186 $>\mathrm{t}$ tabel 2,02, dapat disimpulkan bahwa enterprise risk management memilikikontribusi terhadap nilai perusahaan. Nilai $\mathrm{t}$ positif menunjukkan bahwa $\mathrm{X}$ enterpriserisk management mempunyai hubunganyang Nilai $\mathrm{t}$ positif menunjukkan bahwa $\mathrm{X}$ enterpriserisk management mempunyai hubunganyang positif arah dengan Y nilai perusahaan. Jadi dapat disimpulkanriskmanagement

memilikipengaruh signifikan terhadap nilai perusahaan.

\section{Simpulan dan Saran}

Berdasarkan hasil penelitian yang sudah dilakukan diketahui bahwa penerapan enterprise risk management (COSO) padaperusahaan manufaktur di Indonesia sudah efisien, terbukti dengan hasil olah statistic yang menunjukan rata-rata penerapannya sudah mencapai angka $78 \%$. Nilai perusahaannya pun dalam kondisi yang baik dimana nilai rata-ratanya $62,3 \%$. Penerapan enterprise risk management (COSO) pun berpengaruh terhadap nilai perusahaan, diketahui bahwa diperoleh nilai signifikan $0,00<0,05$. Dapat dilihat bahwa enterprise risk management berpengaruh baik terhadap nilai perusahaan.

Karena penelitian ini berhasil membuktikan bahwa terdapat pengaruh positif antara penerapan enterprise riskmanagement (COSO) terhadap nilaiperusahaan, maka dapat digali lagi variable lain, jumlah perusahaan yang diteliti, jenis perusahaan yang lain, menggunakan metode lain, atau dengan menggunakan standar manajemen risiko yang lain, yaitu ISO 31000.Karena di Indonesia yang standar yang berlaku untuk mengukur penerapan manajemen risiko ada 2 yaitu COSO dan ISO 31000 .

\section{Daftar Pustaka}

Baxter, R. et al., 2012. Enterprise RiskManagement Program Quality: Contemporary Accounting Research, Forthcoming.

Beasley, M.S., Clune, R, dan Hermanson, D.R. 2005. Enterprise RiskManagement: An Empirical Analysis of Factors Associated with the Extent of Implementation. Journal of Accounting and Public Policy, Vol.24. pp 521-531.

Beasley, Mark, Clune, R, dan Hermanson, D. R. (2005). "Enterprise RiskManagement: An Empirical Analysisof Factor Associated with the Extend of Implementation". Journal of Accounting and Public Policy, 24.

COSO (2004).Enterprise risk managementIntegrated FrameworkKomite Nasional Kebijakan Governance(KNKG). "Pedoman 
PenerapanManajemen Risiko Berbasis

Governance". 2011.

Kumala, Magda Subowo dan Indah

Aniskurlillah. "Faktor-Faktor yangBerpengaruh Terhadap Luas Pengungkapan Manajemen Risiko". Accounting Analysis Journal, Vol. 3 No. 1, hlm.18-25. 2014.

Meulbroek, L.K. (2002). Integrated RiskManagement for the Firm: A Senior.

Nocco, B. W., R.M. Sltulz. 2006.Enterprise Risk Management: Theoryand Practice. Journal of AppliedCorporate Finance, 18 (4): 8-20.

Putri, Enesti Eka. 2013. "Pengaruh Komisaris independen, komite manajemen risiko, reputasi auditor dan konsentrasi kepemilikan terhadap pengungkapan enterprise risk management (Dimensi COSO ERM Framework), Skripsi UIN.Jakarta.

www.idx.co.id,Laporan Keuangan Tahunan Perusahaan Manufaktur di BEI 